\title{
Keringő mikroRNS-ek az endokrin daganatok diagnosztikájában
}

\author{
Decmann Ábel dr. ${ }^{1}$ - Perge Pál dr. ${ }^{1}$ - Nagy Zoltán dr. ${ }^{1}$ \\ Butz Henriett dr. ${ }^{2}$ - Patócs Attila dr. ${ }^{2,3}$ - Igaz Péter dr. ${ }^{1}$ \\ ${ }^{1}$ Semmelweis Egyetem, Általános Orvostudományi Kar, II. Belgyógyászati Klinika \\ ${ }^{2}$ MTA-SE Molekuláris Medicina Kutatócsoport, Budapest \\ ${ }^{3}$ MTA-SE Lendület „Örökletes endokrin daganatok” Kutatócsoport, Budapest
}

\begin{abstract}
A mikroRNS-ek (miRNS, miR) rövid - 19-25 nukleotidból álló - érett formájukban egyszálú, nem kódoló RNSmolekulák, amelyek a génexpressziót fóként poszttranszkripcionális szinten befolyásolják. A mikroRNS-ek szerepet játszanak élettani folyamatokban, például a sejtdifferenciálódás és -proliferáció szabályozásában, egyedfejlődésben, vérképzésben, sejthalálban, míg aberráns expressziójuk számos betegség, köztük autoimmun betegségek, gyulladások, vascularis betegségek vagy daganatok kialakulása során megfigyelhető. A mikroRNS-ek szövetspecifikus módon fejeződnek ki. Szöveti megjelenésük mellett különböző testfolyadékokban is megtalálhatóak. Így például a vérben, az anyatejben, az ondóban, nyálban, vizeletben stb. A testfolyadékokban megjelenő mikroRNS-ek, így különösen a vér keringő mikroRNS-ei, a daganatok kórisméjében mint minimálisan invazív diagnosztikai eszközök jöhetnek szóba. Az endokrin daganatokra jellemző leírt keringő mikroRNS-kifejeződések száma eddig alacsony, főként a papillaris pajzsmirigy-carcinomára, mellékvesekéreg-carcinomára, petefészekrákra, illetve egyes neuroendokrin tumorokra szorítkozik. Tekintettel arra, hogy e daganatok egy részének szövettani diagnózisa, a malignitás megállapítása nehéz, a keringő mikroRNS-ek kutatásában jelentős távlatok rejlenek. Orv. Hetil., 2017, 158(13), 483-490.
\end{abstract}

Kulcsszavak: mikroRNS, daganat-biomarker, pajzsmirigydaganat, mellékvesekéreg-carcinoma, petefészek-daganat

\section{Circulating microRNAs in the diagnostics of endocrine neoplasms}

\begin{abstract}
MicroRNAs (miRNA, miR) are short - 19-25 nucleotide long - single stranded (in their mature form), non-coding RNA molecules that regulate gene expression mostly at the posttranscriptional level. microRNAs are involved in the regulation of various physiological processes such as cell differentiation and proliferation, development, haematopoesis, cell death, while their aberrant expression is observed in numerous diseases, like autoimmune disorders, inflammations, vascular diseases or tumorigenesis. microRNAs are expressed in a tissue specific fashion. Beyond their appearance in tissues, they can be found in body fluids as well. microRNAs are present in blood, mother milk, semen, saliva, urine, etc. MicroRNAs in body fluids, especially the blood-borne circulating microRNAs can be exploited as minimally invasive biomarkers of tumor diagnosis. The number of endocrine tumor-associated circulating microRNA alterations is relatively low, mostly described for papillary thyroid cancer, adrenocortical cancer, ovarian and neuroendocrine tumors. As the histological diagnosis including the establishment of malignancy of some of these neoplasms is difficult, studies on circulating microRNAs might have great perspectives.
\end{abstract}

Keywords: microRNA, tumor biomarker, thyroid neoplasm, adrenocortical carcinoma, ovarian neoplasm

Decmann, Á., Perge, P., Nagy, Z., Butz, H., Patócs, A., Igaz, P. [Circulating microRNAs in the diagnostics of endocrine neoplasms]. Orv. Hetil., 2017, 158(13), 483-490.

(Beérkezett: 2017. január 14.; elfogadva: 2017. február 13.)

\section{Rövidítések}

ACC = adrenocorticalis carcinoma (mellékvesekéreg-carcino$\mathrm{ma}) ; \mathrm{FNAB}=$ (fine needle aspiration biopsy) vékonytü-aspirációs citológiai vizsgálat; miR, miRNS = mikroRNS; PTC = (papillary thyroid carcinoma) papillaris pajzsmirigy-carcinoma; RNS = ribonukleinsav
A mikroRNS-ek (miRNS, miR) rövid - 19-25 nukleotidból álló - érett formájukban egyszálú, nem kódoló RNS-molekulák, amelyek a génexpressziót fóként poszttranszkripcionális szinten befolyásolják. E hatásukat a DNS szekvenciájának módosítása nélkül fejtik ki, 
így az epigenetikus szabályozás részei. A mikroRNS-gének több ezres nagyságrendben találhatóak a humán genomban (miRbase adatbázis jelenleg 2588 érett humán mikroRNS-t listáz), és a legújabb adatok alapján a fehérjét kódoló gének 30-60\%-át képesek befolyásolni [1]. Szövetspecifikus kifejeződés jellemző rájuk, ezért a különböző szövetek mikroRNS-mintázata egymástól eltérő. Fontos szerepet töltenek be számos élettani folyamatban, úgymint a sejtdifferenciálódásban, sejtproliferációban, egyedfejlődésben, vérképzésben, sejthalálban, míg aberráns expressziójuk számos betegség, köztük autoimmun betegségek, gyulladások, vascularis betegségek vagy daganatok kialakulását okozhatja $[2,3]$. Az Y-kromoszóma kivételével az összes emberi kromoszómán megtalálhatóak a mikroRNS-gének. Túlnyomó részük a genom 90\%-át kitevő, fehérjét nem kódoló régióban helyezkedik el, az úgynevezett 'sötét anyagban', amelyet korábban 'szemét DNS'-nek tartottak. A fent említett funkciók miatt azonban aligha lehet továbbra is ezt a megnevezést használni ezekre a régiókra. További mikroRNS-gének találhatók a fehérjét kódoló régiókban is, intronokban, exonokban, illetve mindkettőben egyszerre (úgynevezett kevert mikroRNS-gének). E gének konzerváltságára utal, hogy szerkezetük hasonlósága felfedezhető a törzsfejlődés nagyon különböző szintjén álló fajokban is [4].

\section{A mikroRNS-ek bioszintézise}

A legtöbb mikroRNS-gént a sejtmagban az RNS-polimeráz-II írja át elsődleges mikroRNS-sé (pri-miRNS) (1. ábra). A transzkripciót fejlődés- és szövetspecifikus módon elősegíthetik (enhancer) vagy csendesíthetik (silencer) egyes faktorok, illetve befolyásolhatják kromatinmódosulások, transzkripciós faktorok csakúgy, mint a többi fehérjét kódoló gént. Ezután egy összetett érési folyamat következik, amelyek között a kanonikus útvonal a legismertebb és legáltalánosabb. Egy mikroprocesszor komplex, amely a Drosha és DGCR8 (DiGeorge syndrome critical/chromosomal region 8) fehérjékből áll, hasítja az elsődleges miRNS-t körülbelül 60-80 nukleotidból álló kettős RNS-láncú, szerkezetében hajtűszerű (stem-loop, hairpin, Haarnadel) prekurzor mikroRNS-sé (pre-miRNS). A keletkezett pre-miRNS a sejtmagból a citoplazmába kerül a Ran GTP-áz-függő Exportin-5 fehérje közremúködésével. Ezt követően egy endoribonukleáz (Dicer) formálja tovább, és alakul ki az érett mikroRNS. Egyes prekurzor mikroRNS-eknek akár két különböző hasítási helye is lehet. Ezt nevükben jelöljük aszerint, hogy ez az 5 ' vagy $3^{\prime}$ véghez van közelebb (például miR-483-5p, illetve miR-483$3 \mathrm{p}$ ). A citoplazmában TRBP (transactivation-responsive RNA-binding protein), az AGO2 (Argonaute-2) és a Dicer fehérjékkel együtt képezi a RISC-et (RNA-induced silencing complex). A helikázaktivitással rendelkező RISC segítségével keletkeznek az egyszálú, mRNS-hez (messenger RNS) kötődni képes mikroRNS-ek, amelye-

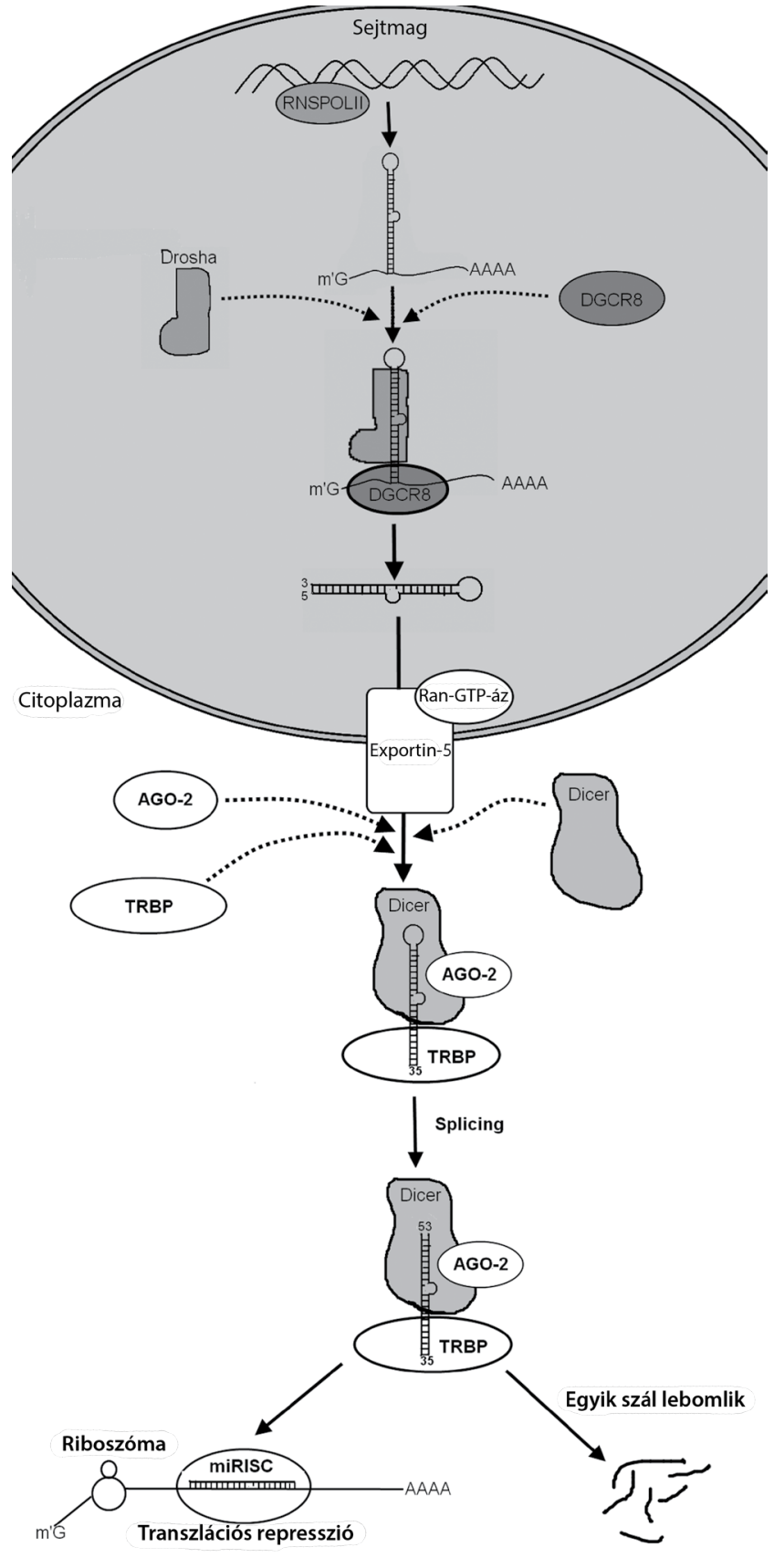

1. ábra

ket ugyanez a komplex egyben stabilizál is. A másik szál az esetek többségében, de nem minden esetben, lebomlik [2].

\section{A mikroRNS-ek funkciói}

A mikroRNS-ek fó funkciója a mRNS-ek kifejeződésének befolyásolása a citoplazmában, amely révén a génexpressziót poszttranszkripciós szinten befolyásolják. Az érett, egyszálú miRNS - a RISC részeként - kötődik a cél mRNS $3^{\prime}$ át nem íródó régiójához (3' UTR). Az állatokra jellemző részleges komplementaritás esetén a 
transzláció gátlódik, míg teljes komplementaritás és a következetes mRNS-degradáció a növényeknél fordul elő inkább [5]. A mikroRNS-ek jellemző tulajdonságai a redundancia és a pleiotropia. Redundánsak, ugyanis egy mikroRNS-szekvencia a genom több, eltérő helyéről is kifejeződhet, illetve egy mRNS-t akár több száz különböző mikroRNS is célba vehet. Viszont egy mikroRNS - pleiotrop tulajdonsága miatt - akár több száz mRNSsel is kapcsolatba léphet [6]. A génexpresszió szabályozásában általában szupresszív szerepet töltenek be, de leírták már a génexpressziót direkt vagy indirekt módon elősegítő hatásukat is [1].

Mivel a mikroRNS-ek részt vesznek a sejtek differenciációjának és proliferációjának szabályozásában is, így megváltozott kifejeződésük tumorok kialakulását segíthetik elő. Ezek alapján két csoportra oszthatóak: tumorszuppresszorokra és onkogénekre (onkomiR). Azon mikroRNS-ek, amelyek elősegítik a proliferációt, inváziót, angiogenesist vagy csökkentik a tumorszuppresszor gének expresszióját, azokat onkogén mikroRNS-eknek nevezzük. Ezzel szemben, amelyek a differenciációban, apoptózisban szerepelnek vagy csökkentik az onkogén aktivitást, tumorszuppresszor mikroRNS-ek. Daganatos szövetekben a szabályozás szintjén az onkogén miRNS-ek expressziója általában fokozott, míg a tumorszuppreszszor miRNS-ek expressziója csökkent. A miRNS-ek szövetspecifikus tulajdonsága miatt lehetséges az, hogy egyes mikroRNS-ek az egyik szövetben onkogénként, míg másik szövetben tumorszuppresszorként mutatkoznak. Ilyen például a miR-503, ami mellékvesekéreg-carcinomában felülexpresszálódik, ugyanakkor hypophysistumorokban alulexpresszálódik [7, 8].

A mikroRNS-ek nemcsak szövetekben, hanem különféle testfolyadékokban is megtalálhatóak. Többek között megtalálhatóak a vérben, anyatejben, ondóban, nyálban, bronchialis váladékban, peritonealis nedvben, könnyben és a vizeletben is. Ezek közül legnagyobb koncentrációban az anyatej tartalmaz miRNS-eket $\left(10^{5} \mu \mathrm{g} / \mathrm{L}\right)$, míg a vizelet a legkisebb koncentrációban $\left(10^{2} \mu \mathrm{g} / \mathrm{L}\right)$ [9]. A sejtekből kijutásra három fóbb lehetôség ismert: 1. gyulladás, illetve necrosis révén passzív kiáramlással; 2. aktív szekrécióval extracelluláris vesiculumok (például microvesiculum, apoptotikus test, exoszóma); 3. vagy makromolekuláris komplexek (például AGO [95\%-ban ehhez van kötve] vagy lipoproteinek [például high density lipoprotein, azaz HDL]) segítségével. Az extracelluláris mikroRNS-ek stabilak és nagyon ellenállók különböző ártalmakkal szemben (magas/alacsony $\mathrm{pH}$, forralás, tárolás hosszú ideig) [10]. A sejtek többsége juttat így mikroRNS-t a környezetébe, ezért az extracelluláris vesiculumok is kimutathatóak vérből, vizeletből, nyálból, anyatejből, epéből stb. Az exoszómák 30-120 nm átmérôjű vesiculumok, amik a sejten belüli multivesicularis testekből alakulnak ki, fö összetevőik között lipidek, fehérjék és nukleinsavak (mikroRNS, mRNS) találhatók. Felsorolt tulajdonságaik miatt potenciálisan jó biomarkerek lehetnek az extracelluláris vesiculumok hordozta mikroRNS-ek különböző betegségek diagnózisában, illetve prognózisában [11]. Az, hogy a mikroRNSek vizsgálata szérumból vagy plazmából jár-e nagyobb hozammal, nincs még pontosan tisztázva. Egyes vizsgálatok szerint a mikroRNS-szintek erősen korrelálnak szérum- és plazmaminták között, míg mások magasabb koncentrációt mértek szérum vizsgálatakor [12].

$\mathrm{Az}$ anyatejben fellelhető mikroRNS-eknek további érdekes szerepük lehet, mivel az egyének (anya-gyermek) közötti kommunikációban játszhatnak szerepet. A funkcionális hipotézis szerint az emésztőrendszerbe bekerült mikroRNS-ek felszívódnak a keringésbe és ezen keresztül jutnak el az utód sejtjeihez, amelyek génexpressziós mintázatát befolyásolhatják. A másik, ezt a mechanizmust tagadó nutricionális hipotézis szerint ugyanakkor az anyatejben levő mikroRNS-ek nem szívódnak fel a keringésbe, csupán táplálékként szolgálnak az utód számára [13].

Diagnosztikai és prognosztikai jelentőségük mellett élettani szerepük is lehet a keringő mikroRNS-eknek. Ahogyan egyes sejtek szekretálnak mikroRNS-eket a környezetükbe, illetve a vérkeringésbe, úgy feltételezhető, hogy ezek a mikro- vagy nanovesiculák más sejteket vesznek célba, és a benne levő mikroRNS-ek ott fejtenek ki poszttranszkripcionális módosításokat. Célba vehetnek más sejteket egyénen belül, más sejteket azonos fajba tartozó egyedeknél (1. anyatej-mikroRNS) vagy akár más sejteket eltérő fajokban [14]. Így hormonszerü hatást is tulajdoníthatunk a mikroRNS-eknek.

\section{MikroR NS mint biomarker}

Napjainkban gyorsuló ütemben fedeznek fel újabb és újabb potenciális biomarkerként használható mikroRNSeket. Számos kutatás célja az egyes betegségekre, állapotokra jellemző mikroRNS-mintázat megtalálása. Kiragadott példákat mutatva, a szakirodalomban leírták már felhasználhatóságukat terhesség alatti intrahepaticus cholestasis [15] vagy akut pulmonalis embolia diagnózisában [16]. Ezek mellett daganatos betegségekre jellemző mikroRNS-eket is nagy számban találunk az irodalomban. A daganatos betegségeknél nagyságrendekkel több kutatás folyik világszerte, ugyanis a daganatok diagnózisa és prognosztikája is jelenleg sokszor nagy kihívást jelentő folyamat, amelyet vérvétellel és laboratóriumi diagnosztikával helyettesíteni lehetne (noninvazív biomarker).

Összefoglaló cikkünkben az endokrin daganatok kórisméjében felhasználható társuló keringő mikroRNS markereket mutatjuk be. E daganatok szövettani diagnózisa sokszor nehéz, így például a differenciált pajzsmirigyrákok és mellékvesekéreg-carcinoma szövettani vizsgálata nagy gyakorlatot igényel, és így a malignitást jelző biomarkereknek nagy klinikai jelentősége lenne. 


\section{A keringő mikroRNS-ek szerepe endokrin daganatokban}

\section{Pajzsmirigy}

A papillaris pajzsmirigy-carcinoma (PTC) az egyik leggyakoribb rosszindulatú endokrin daganat, incidenciája az 1970-es évektől 2010-ig kis híján megháromszorozódott (100 000 emberból 4,2-ról 11,1-re emelkedett) [17]. A szövettani vizsgálat még napjainkban is a diagnózis arany standardja, ezért számos vizsgálatot végeztek már szöveti mikroRNS-ek feltérképezésére. Az utóbbi időkben a felfedezett keringő mikroRNS-ek száma is nő. Összehasonlítva egészséges emberek vagy jóindulatú pajzsmirigygöbökkel bírók szérumaival, a let-7-e, a miR151-5p és a miR-222 felülexpresszálódott papillaris pajzsmirigy-carcinomában (noha a let-7 család daganatos szövetekben általában inkább alulexpresszálódik) kínai populációban (1. táblázat) [18, 19]. Kaukázusi népességben ugyanakkor a $m i R-190$ felül-, illetve a $m i R-95$ alulexpresszálódott egészséges emberekhez és jóindulatú elváltozásokhoz viszonyítva [20]. Egy újabb tanulmányban a PTC-s betegeket is két csoportra osztották nyirokcsomóáttét megléte alapján. Magasabb koncentrációban jelent meg a miR-146b és a miR-155 egészségesekhez viszonyítva, illetve a $m i R-155$ magasabb kifejeződése utalhat arra, hogy a környező nyirokcsomók is érintettek [21]. In vitro kísérletben, exoszomális mikroRNS-ek vizsgálatával a $m i R-146 b$ és a $m i R-222$ magasabb expresszióját találták [22]. További két mikroRNS, amelyek expresszióját jellemzőnek találták PTC-ben, a miR- 25-3p és a $m i R-451$, amelyek szintje a daganat eltávolítása után csökkent, ezzel is bizonyítva az összefüggést [23]. Egy további tanulmány számol be arról, hogy vékonytü-aspirációs citológiai minták és PTC-s betegek szérumát összehasonlították egészséges emberekével, és leírja, hogy a miR-30a-5p szintje magasabb PTC-ben. (A szérum-, illetve FNAB-mintáknál is [24].) Rekurráló papillaris pajzsmirigy-carcinomákat vizsgálva találták, hogy a $m i R-221, m i R-222$ és a $m i R-146 b$ kifejeződése szignifikánsabban magasabb volt a daganatos betegekben egészséges emberekhez viszonyítva. A miR-146b és a miR-222 markerek használatával a jövőben várhatóan el lehetne különíteni a prognózisukban rosszabb carcinomákat. Prognózist megjósoló potenciális biomarker lehet a miR-203 is, ugyanis magasabb szintjét találták azoknál, akiknél a betegség rosszabb prognózisú volt [25]. Akiknél ez megfigyelhető, akár erősebb kemoterápiás kezelést is kaphatnának [26].

A follicularis pajzsmirigy-carcinomától (FTC) elkülönítő diagnózisban segíthet a $m i R-21-5 p$ és a $m i R-181 a-$ $5 p$, ugyanis a $m i R-21-5 p$ szignifikánsan inkább follicularis cacrcinomában, míg a $m i R-181 a-5 p$ szignifikánsan inkább PTC-ben volt felülexpresszálódva összehasonlító elemzéssel [27]. Autoimmun pajzsmirigybetegségek tekintetében azt lehet mondani (ahol a Basedow-Gravesés a Hashimoto-thyreoiditises betegek szérumát hasonlították össze egészséges emberek szérumával), hogy az egészségesekhez viszonyítva a $m i R-22$, a $m i R-375$, illetve a $m i R-451$ mindkét betegségben magasabb koncentrációban volt jelen, míg a $m i R-16$ csupán a Graves-betegek szérumában [28].

1. táblázat |A pajzsmirigy daganatos állapotaiban felfedezett keringő mikroRNS-ek

\begin{tabular}{|c|c|c|c|c|c|}
\hline Endokrin tumor & miRNS & miRNS-szint-változás & Minta & Referencia & Megjegyzés/vizsgálati módszer \\
\hline \multirow[t]{10}{*}{$\begin{array}{l}\text { Papillaris } \\
\text { pajzsmirigy- } \\
\text { carcinoma }\end{array}$} & $\begin{array}{l}\text { let-7-e; } \\
\text { miR-151-5p; } \\
\text { miR-222 }\end{array}$ & $\begin{array}{l}\text { Emelkedett, } \\
\text { jóindulatú vagy egészséges } \\
\text { mintához hasonlítva }\end{array}$ & Szérum & {$[18]$} & Solexa szekvenálás \\
\hline & $\begin{array}{l}\text { miR-221; } \\
\text { miR-222; } \\
\text { miR-146b }\end{array}$ & $\begin{array}{l}\text { Emelkedett, nem rekurráló } \\
\text { pajzsmirigytumorhoz hasonlítva }\end{array}$ & Plazma & {$[26]$} & $\begin{array}{l}\text { Rekurráló; Exiqon microarray } \\
\text { profilozás (PCR) }\end{array}$ \\
\hline & $\operatorname{miR}-190$ & $\begin{array}{l}\text { Emelkedett, egészséges vagy } \\
\text { jóindulatú mintához hasonlítva }\end{array}$ & Szérum & {$[20]$} & TaqMan array profilozás (PCR) \\
\hline & $\operatorname{miR}-95$ & Csökkent & & & \\
\hline & $\begin{array}{l}\text { miR-146b; } \\
\text { miR-155 }\end{array}$ & $\begin{array}{l}\text { Emelkedett, jóindulatú } \\
\text { mintákhoz hasonlítva }\end{array}$ & Plazma & {$[21]$} & TaqMan array profilozás (PCR) \\
\hline & $\begin{array}{l}\text { miR-146b; } \\
\text { miR-222 }\end{array}$ & $\begin{array}{l}\text { Emelkedett, egészséges mintához } \\
\text { hasonlítva }\end{array}$ & Exoszomális & {$[22]$} & TaqMan array profilozás (PCR) \\
\hline & $\begin{array}{l}\text { miR-25-3p; } \\
m i R-451\end{array}$ & $\begin{array}{l}\text { Emelkedett, egészséges vagy } \\
\text { jóindulatú mintához hasonlítva }\end{array}$ & Plazma & {$[23]$} & $\begin{array}{l}\text { Agilent microarray profilozás } \\
\text { (PCR) }\end{array}$ \\
\hline & $m i R-30 a-5 p$ & $\begin{array}{l}\text { Emelkedett, egészséges } \\
\text { mintákhoz hasonlítva }\end{array}$ & $\begin{array}{l}\text { Szérum, illetve } \\
\text { FNAB }\end{array}$ & {$[24]$} & Qiagen array profilozás (PCR) \\
\hline & $m i R-21$ & $\begin{array}{l}\text { Csökkent, follicularis pajzsmirigy- } \\
\text { carcinomához hasonlítva }\end{array}$ & $\begin{array}{l}\text { Szérum } \\
\text { exoszomális }\end{array}$ & {$[27]$} & $\begin{array}{l}\text { Exiqon microarray profilozás } \\
\text { (PCR) }\end{array}$ \\
\hline & $m i R-181 a-5 p$ & Emelkedett & & & \\
\hline
\end{tabular}


2. táblázat |A mellékvese daganatos állapotaiban felfedezett keringő mikroRNS-ek

\begin{tabular}{|c|c|c|c|c|c|}
\hline Endokrin tumor & miRNS & miRNS-szint-változás & Minta & Referencia & Megjegyzés/vizsgálati módszer \\
\hline \multirow[t]{4}{*}{$\begin{array}{l}\text { Mellékvesekéreg- } \\
\text { carcinoma }\end{array}$} & miR-195 & $\begin{array}{l}\text { Csökkent, mellékvesekéreg- } \\
\text { adenomához hasonlítva }\end{array}$ & Szérum & {$[29]$} & TaqMan array profilozás (PCR) \\
\hline & $m i R-483-5 p$ & Emelkedett & & & \\
\hline & $\begin{array}{l}\text { miR-100; } \\
\text { miR-181b; } \\
\text { miR-184; } \\
\text { miR-210; } \\
\text { miR-483-5p }\end{array}$ & $\begin{array}{l}\text { Emelkedett, mellékvesekéreg- } \\
\text { adenomához hasonlítva }\end{array}$ & Plazma & {$[31]$} & $\begin{array}{l}\text { Affymetrix array profilozás } \\
\text { (PCR) }\end{array}$ \\
\hline & $\begin{array}{l}\operatorname{miR}-34 a \\
m i R-483-5 p\end{array}$ & $\begin{array}{l}\text { Emelkedett, mellékvesekéreg- } \\
\text { adenomához hasonlítva }\end{array}$ & Szérum & {$[30]$} & TaqMan array profilozás (PCR) \\
\hline $\begin{array}{l}\text { Malignus } \\
\text { pheochromocytoma }\end{array}$ & $\begin{array}{l}\text { miR-483-5p; } \\
m i R-101 ; m i R-183\end{array}$ & $\begin{array}{l}\text { Emelkedett, jóindulatú } \\
\text { pheochromocytomához hasonlítva }\end{array}$ & Szérum & {$[33]$} & Exiqon array profilozás (PCR) \\
\hline
\end{tabular}

3. táblázat | Ivarszervek daganatos állapotaiban felfedezett keringő mikroRNS-ek

\begin{tabular}{|c|c|c|c|c|c|}
\hline Endokrin tumor & miRNS & miRNS-szint-változás & Minta & Referencia & Megjegyzés/vizsgálati módszer \\
\hline \multirow[t]{5}{*}{$\begin{array}{l}\text { Csírasejtes } \\
\text { heretumor }\end{array}$} & $\begin{array}{l}\text { miR-371-3p; } \\
\text { miR-372; } \\
\text { miR-373; } \\
\text { miR-302 }\end{array}$ & $\begin{array}{l}\text { Emelkedett, egészséges és } \\
\text { jóindulatú csírasejtes tumorhoz } \\
\text { hasonlítva }\end{array}$ & Szérum & {$[34]$} & TaqMan array profilozás (PCR) \\
\hline & $m i R-371-3 p$ & $\begin{array}{l}\text { Emelkedett, posztoperatív } \\
\text { mintához hasonlítva }\end{array}$ & Szérum & {$[35]$} & TaqMan array profilozás (PCR) \\
\hline & $\begin{array}{l}\text { miR-367-3p; } \\
\text { miR-371-3p; } \\
\text { miR-372-3p; } \\
\text { miR-373-3p }\end{array}$ & $\begin{array}{l}\text { Emelkedett, egészséges mintához } \\
\text { hasonlítva }\end{array}$ & Szérum & {$[36]$} & Qiagen array profilozás (PCR) \\
\hline & $m i R-371-3 p$ & $\begin{array}{l}\text { Emelkedett, egészséges } \\
\text { mintákhoz hasonlítva }\end{array}$ & Szérum & {$[37]$} & TaqMan array profilozás (PCR) \\
\hline & $m i R-571-3 p$ & $\begin{array}{l}\text { Emelkedett, posztoperatív } \\
\text { mintához hasonlítva }\end{array}$ & Szérum & {$[38]$} & TaqMan array profilozás (PCR) \\
\hline \multirow[t]{8}{*}{$\begin{array}{l}\text { Petefészek- } \\
\text { carcinoma }\end{array}$} & $\begin{array}{l}\text { miR-21; miR-92; } \\
\text { miR-93; miR-29a; } \\
\text { miR-126 }\end{array}$ & Emelkedett & Szérum & {$[39]$} & \\
\hline & $\begin{array}{l}\text { miR-200b; } \\
\text { miR-200c; } \\
\text { miR-103 }\end{array}$ & $\begin{array}{l}\text { Emelkedett, egészséges } \\
\text { petefészek epithelsejtekhez } \\
\text { viszonyítva }\end{array}$ & Szérum & {$[40]$} & $\begin{array}{l}\text { Serosus petefészekcarcinoma- } \\
\text { sejtvonal; Exiqon szekvenálás }\end{array}$ \\
\hline & $m i R-21$ & $\begin{array}{l}\text { Emelkedett, egészséges } \\
\text { mintákhoz hasonlítva }\end{array}$ & Szérum & {$[41]$} & TaqMan array profilozás (PCR) \\
\hline & $m i R-221$ & $\begin{array}{l}\text { Emelkedett, egészséges } \\
\text { mintákhoz hasonlítva }\end{array}$ & Szérum & {$[42]$} & Qiagen array profilozás (PCR) \\
\hline & $\operatorname{miR}-92$ & $\begin{array}{l}\text { Emelkedett, egészséges } \\
\text { mintákhoz hasonlítva }\end{array}$ & Szérum & {$[43]$} & $\begin{array}{l}\text { Takara Bio array profilozás } \\
\text { (PCR) }\end{array}$ \\
\hline & $\begin{array}{l}\operatorname{miR}-205 \\
\text { let-7f }\end{array}$ & $\begin{array}{l}\text { Emelkedett, egészséges } \\
\text { mintákhoz viszonyítva }\end{array}$ & Plazma & {$[44]$} & TaqMan array profilozás (PCR) \\
\hline & $\begin{array}{l}\text { let-7i-5p; } \\
\text { miR-152; } \\
\text { miR-122-5p; } \\
\text { miR-25-3p }\end{array}$ & $\begin{array}{l}\text { Csökkent, jóindulatú } \\
\text { elváltozásokhoz hasonlítva }\end{array}$ & Szérum & [49] & Roche array profilozás (PCR) \\
\hline & $\begin{array}{l}\text { miR-373; } \\
\text { miR-200a; } \\
\text { miR-200b; } \\
\text { miR-200c }\end{array}$ & $\begin{array}{l}\text { Emelkedett, jóindulatú } \\
\text { elváltozásokhoz hasonlítva }\end{array}$ & $\begin{array}{l}\text { Szérum } \\
\text { exoszomális }\end{array}$ & {$[50]$} & TaqMan array profilozás (PCR) \\
\hline
\end{tabular}




\section{Mellékvese}

Vizsgálatok eddig döntően a mellékvesekéreg daganatai által expresszált keringő miRNS-ekre terjedtek ki, azon belül is a mellékvesekéreg-carcinoma (ACC) áll a kutatások fókuszában. A mellékvesekéreg-carcinoma ritka, rossz prognózisú daganat. A prognózist tovább rontja a diagnózis alkotásának nehézsége és a limitált terápiás lehetőségek is. Mellékvese-adenomával összehasonlítva, a miR-195 alulexpresszálódását, illetve a miR-34a és a miR-483-5p felülexpresszálódását találták, valamint a miR-483-5p prognosztikai jelentőségét is felvetették (2. táblázat) $[29,30]$. Kutatócsoportunk is vizsgálta korábban a mellékvesekéreg-carcinoma keringő mikroRNS-mintázatát. Ugyancsak mellékvesekéreg-adenomával összehasonlítva a $m i R-100$, a $m i R-181 b$, a $m i R-184$, a $m i R-210$, illetve a $m i R-483-5 p$ felülexpresszálódása volt szignifikáns [31]. Egy másik tanulmányunkban bemutattuk, hogy a $m i R-483-5 p$ kifejeződését nem befolyásolja dexamethason vagy adrenokortikotropin adása, ami megerősíti, hogy az ACC preoperatív diagnosztikájában potenciális szerepe lehet [32]. Egy vizsgálat számolt be eddig a malignus pheochromocytomában szenvedő betegekre jellemző keringő mikroRNS-ekről. Eszerint a $m i R-483-5 p$, a $m i R-101$, illetve a $m i R-183$ jó diagnosztikus markerek lehetnek a jövőben, amelyeket a jó- és rosszindulatú pheochromocytomák elkülönítésére lehetne használni [33]. Tekintettel arra, hogy a phaeochromocytoma rosszindulatúságát szövettani vizsgálattal megállapítani nem lehet, csak áttétek jelenléte esetén, egy malignitást jelző keringő mikroRNS klinikailag nagy jelentőségű lenne.

\section{Ivarszervek}

A here csírasejtes tumoránál vizsgálták a keringő mikroRNS-mintázatot, és a $m i R-371-3 p, m i R-372$, miR373 és a miR-302 szignifikánsan magasabb kifejeződését találták (3. táblázat). Bár a mikroRNS-ek szintje a patológiai és klinikai stádiumokkal pozitívan korrelál, az AFP- (alfa-fötoprotein-) szinttel kevésbé [34-36]. A legtöbb leírt miRNS specifikus a here csírasejtes daganatával, de a miR-371 korrelál a kutatás szerint a legjobban a daganat méretével. Ezért talán célszerúbb a jövőben egy panelt készíteni és több mikroRNS-t egyszerre vizsgálni [37]. Elörehaladott stádiumban és nonseminoma típusban emelkedettebb a $m i R-571 a-3 p$ szintje [38].

$\mathrm{Az}$ ovariumcarcinoma esetében a keringő $m i R-21$, miR-92, miR-93, miR-29a és a miR-126 szintjét találták felülexpresszáltnak. Továbbá, normális CA-125-szint mellett is megfigyelhetó volt egyes kutatásoknál a $m i R$ 21, a $m i R-92$ és a $m i R-93$ magasabb szintje. Ez a tény megkérdőjelezheti az eddig használt biomarker pontosságát [39]. Serosus epithelialis petefészek-carcinomában szenvedő betegek szérumában emelkedett miR-200b- és $c$, illetve $m i R-103$-szintet találtak [40]. A $m i R-21$ és $m i R-221$ szintje korrelál a rosszabb kimenetellel, a FIGO-beosztással és a tumornagysággal [41, 42]. A miR-92 szintje összefüggést mutatott a magasabb nyirokcsomó-invázióval és a klinikai stádiummal [43]. A tumor korai detektálására alkalmas lehet a let-7-f, illetve a $m i R-205[44]$.

\section{Neuroendokrin tumorok}

A keringő mikroRNS-ek szerepét neuroendokrin tumorokban (NET) egyelőre kevés kutatás vizsgálta. Főként a hasnyálmirigy és a vékonybél NET-jeit vizsgálták eddig. A miR-1290 a hasnyálmirigy neuroendokrin tumoraiban fokozott expresszióját írták le, amely adenocarcinomától való differenciáldiagnózisban jelenthet segítséget (4. táblázat) [45]. Vékonybél neuroendokrin tumoros betegek szérumában felülexpresszálódást mutattak ki a $m i R-96$, miR-182, miR-183, miR-196a és miR-200a esetén, míg a $m i R-31, m i R-129-5 p$, miR-133a és $m i R-215$ expreszsziója csökkent volt [46].

4. táblázat | Neuroendokrin daganatos állapotokban felfedezett keringő mikroRNS-ek

\begin{tabular}{|c|c|c|c|c|c|}
\hline Endokrin tumor & miRNS & miRNS-szint-változás & Minta & Referencia & Megjegyzés/vizsgálati módszer \\
\hline \multirow[t]{2}{*}{$\begin{array}{l}\text { Hasnyálmirigy } \\
\text { neuroendokrin daganat }\end{array}$} & $m i R-1290$ & $\begin{array}{l}\text { Emelkedett, jóindulatú } \\
\text { és egészséges mintákhoz } \\
\text { hasonlítva }\end{array}$ & Szérum & {$[45]$} & TaqMan array profilozás (PCR) \\
\hline & $\begin{array}{l}\text { miR-584, } \\
m i R-1285, \\
m i R-550-002410 \\
m i R-1825\end{array}$ & Csökkent & & & \\
\hline \multirow[t]{2}{*}{$\begin{array}{l}\text { Vékonybél } \\
\text { neuroendokrin tumor }\end{array}$} & $\begin{array}{l}\text { miR-96, } \\
\text { miR-182, } \\
\text { miR-183, } \\
\text { miR-196a és } \\
m i R-200 a\end{array}$ & $\begin{array}{l}\text { Emelkedett, egészséges } \\
\text { sejtekhez hasonlítva }\end{array}$ & Szérum & [46] & $\begin{array}{l}\text { Affymetrix array profilozás } \\
\text { (PCR) }\end{array}$ \\
\hline & $\begin{array}{l}\text { miR-31, } \\
\text { miR-129-5p, } \\
\text { miR-133a és } \\
\text { miR-215 }\end{array}$ & Csökkent & & & \\
\hline
\end{tabular}




\section{Következtetések}

2010 óta ismert, hogy a mikroRNS-ek nemcsak szövetekben, hanem különféle testfolyadékokban, váladékokban is megtalálhatóak [9]. Az újonnan felfedezett keringő mikroRNS-ek száma fokozatosan közelít a szövetekben leírt mikroRNS-ek számához, és egyre több eredményt közölnek a keringő mikroRNS-ek diagnosztikus jelentőségéről daganatos betegségekben. Az eredmények között azonban számos eltérés figyelhető meg, ugyanazon daganatok esetében különböző munkacsoportok gyakran teljesen más mikroRNS-mintázatokat írnak le, amiben a mintaválasztás, mikroRNS-analízis és normalizálás különbségei is szerepet játszanak [31], valamint a társbetegségek is fontosak lehetnek. Az endokrin daganatokra vonatkozóan viszonylag kevés adat áll rendelkezésünkre, bár a változás egy év alatt is figyelemreméltó [47]. Egyes endokrin daganatok keringő mikroRNS-einek mintázatának leírása fokozatosan gyarapodik (1. PTC, ACC, csírasejtes heretumor, ovariumcarcinoma), de még lemaradásban vannak más területek vizsgálatához (például gastrointestinalis daganatokhoz) képest. Ezt természetesen megnehezítik azok a tényezők, mint például a pheochromocytoma rendkívül szerteágazó etiológiája [48-50], vagy a mellékvesekéregadenomák különböző hormontermelésének megléte vagy hiánya. Ugyanitt lehetne említeni az agyalapi mirigy daganatait is. További hátrány egyes daganatok alacsony prevalenciája (például mellékvesekéreg-carcinoma), amely nagymértékben megnehezíti a megfelelő nagyságú beteganyagok összegyűjtését. A keringő mikroRNSek vizsgálatában mindazonáltal nagy potenciál létezik, mivel potenciális diagnosztikai, prognosztikai markerek lehetnek a jövőben. Elsősorban olyan állapotok esetén lehetnek különösen hasznosak, amelyek diagnózisa vagy követése klinikailag nehézkes. Továbbá különböző etiológiájú, de azonos manifesztációjú betegségeknél (például pheochromocytoma) a mikroRNS-mintázatból akár az etiológiára is lehetne következtetni.

Anyagi támogatás: E munkát a Nemzeti Kutatási Fejlesztési és Innovációs Hivatal (NKFIH) Dr. Igaz Péter által elnyert K1 15398 számú pályázata támogatta.

Szerzői munkamegosztás: Az összefoglaló cikk megírásában valamennyi szerző részt vett, és a végleges változatát valamennyi szerző elolvasta és jóváhagyta.

Érdekeltségek: A szerzőknek nincsenek érdekeltségeik.

\section{Irodalom}

[1] Malumbres, M.: MiRNAs and cancer: An epigenetics view. Mol. Aspects Med., 2013, 34, 863-874.

[2] Bartel, D. P.: MicroRNAs: Genomics, biogenesis, mechanism, and function. Cell, 2004, 116, 281-297.

[3] Iorio, M. V., Croce, C. M.: Causes and consequences of microRNA dysregulation. Cancer J. NIH Public Access, 2012, 18, 215-222.
[4] Lagos-Quintana, M., Rauhut, R., Meyer, J., et al.: New microRNAs from mouse and human. RNA, 2003, 9, 175-179.

[5] Axtell, M. J., Westholm, J. O., Lai, E. C.: Vive la différence: biogenesis and evolution of microRNAs in plants and animals. Genome Biol., 2011, 12, 221

[6] Olive, V., Minella, A. C., He, L.: Outside the coding genome, mammalian microRNAs confer structural and functional complexity. Sci. Signal., 2015, 368, re2.

[7] Nagy, Z., Igaz, P.: Introduction to microRNAs: Biogenesis, action, relevance of tissue microRNAs in disease pathogenesis, diagnosis and therapy - The concept of circulating microRNAs. EXS, 2015, 106, 3-30.

[8] Zhang, B., Pan, X., Cobb, G. P., et al.: MicroRNAs as oncogenes and tumor suppressors. Dev. Biol., 2007, 302, 1-12.

[9] Weber, J. A., Baxter, D. H., Zhang, S., et al.: The microRNA spectrum in 12 body fluids. Clin. Chem., 2010, 56, 1733-1741.

[10] Jung, M., Schaefer, A., Steiner, I., et al.: Robust microRNA stability in degraded RNA preparations from human tissue and cell samples. Clin. Chem., 2010, 56, 998-1006.

[11] Shababipour, F., Banach, M., Sabebkar, A.: Exosomes as nanocarriers for siRNA delivery: paradigms and challenges. Arch. Med. Sci., 2016, 6, 1324-1326.

[12] Wang, K., Yuan, Y., Cho, J. H., et al.: Comparing the microRNA spectrum between serum and plasma. PLoS ONE, 2012, 7, e41561.

[13] Melnik, B. C., Kakulas, F., Geddes, D. T., et al.: Milk miRNAs: simple nutrients or systemic functional regulators? Nutr. Metab. (Lond.), 2016, 13, 42.

[14] Perge, P., Nagy, Z., Decmann, Á., et al.: Potential relevance of microRNAs in inter-species epigenetic communication, and implications for disease pathogenesis. RNA Biol., 2016 okt 28. 1-11. [Epub ahead of print]

[15] Ma, L., Zhang, X. Q., Zhou, D. X., et al.: Feasibility of urinary microRNA profiling detection in intrahepatic cholestasis of pregnancy and its potential as a non-invasive biomarker. Sci. Rep., 2016, 6, 31535 .

[16] Kessler, T., Erdmann, J., Vilne, B., et al.: Serum microRNA-1233 is a specific biomarker for diagnosing acute pulmonary embolism. J. Transl. Med., 2016, 14, 120.

[17] Cramer, J. D., Fu, P., Harth, K. C., et al.: Analysis of the rising incidence of thyroid cancer using the surveillance, epidemiology and end results national cancer data registry. Surgery, 2010, 148, 1147-1153.

[18] Yu, S., Liu, ., Wang, J., et al.: Circulating microRNA profiles as potential biomarkers for diagnosis of papillary thyroid carcinoma. J. Clin. Endocrinol. Metab., 2012, 97, 2084-2092.

[19] Perdas, E., Stawski, R., Nowak, D., et al.: The role of miRNA in papillary thyroid cancer in the context of miRNA Let-7 family. Int. J. Mol. Sci., 2016, 17, 909.

[20] Cantara, S., Pilli, T., Sebastiani, G., et al.: Circulating miRNA95 and miRNA190 are sensitive markers for the differential diagnosis of thyroid nodules in a Caucasian population. J. Clin. Endocrinol. Metab., 2014, 99, 4190-4198.

[21] Lee, Y. S., Lim, Y. S., Lee, J. C., et al.: Differential expression levels of plasma-derived miR-146b and miR-155 in papillary thyroid cancer. Oral Oncol., 2015, 51, 77-83.

[22] Lee, J. C., Zhao, J. T., Gundara, J., et al.: Papillary thyroid cancerderived exosomes contain miRNA-146b and miRNA-222. J. Surg. Res., 2015, 196, 39-48.

[23] Li, M., Song, Q., Li, H., et al.: Circulating miR-25-3p and miR-45 la may be potential biomarkers for the diagnosis of papillary thyroid carcinoma. PLoS ONE, 2015, 10, e0132403.

[24] Igci, Y. Z., Ozkaya, M., Korkmaz, H., et al.: Expression levels of $m i R-30 a-5 p$ in papillary thyroid carcinoma: A comparison between serum and fine needle aspiration biopsy samples. Genet. Test. Mol. Biomarkers, 2015, 19, 418-423. 
[25] Zheng, J., Li, J.: Serum miRNA-203 as a potential biomarker for papillary thyroid carcinoma. Int. J. Clin. Exp. Med., 2016, 9, 14980-14986.

[26] Lee, J. C., Zhao, J. T., Clifton-Bligh, R. J., et al.: MicroRNA-222 and microRNA-146b are tissue and circulating biomarkers of recurrent papillary thyroid cancer. Cancer, 2013, 119, 4358-4365.

[27] Samsonov, R., Burdakov, V., Shtam, T., et al.: Plasma exosomal miR-21 and miR-181a differentiates follicular from papillary thyroid cancer. Tumor Biol., 2016, 37, 12011-12021.

[28] Yamada, H., Itoh, M., Hiratsuka, I., et al.: Circulating microRNAs in autoimmune thyroid diseases. Clin. Endocrinol. (Oxf.), 2014, 81, 276-281

[29] Chabre, O., Libé, R., Assie, G., et al.: Serum miR-483-5p and miR-195 are predictive of recurrence risk in adrenocortical cancer patients. Endocr. Relat. Cancer, 2013, 20, 579-594.

[30] Patel, D., Boufraqech, M., Jain, M., et al.: MiR-34a and miR-483$5 \mathrm{p}$ are candidate serum biomarkers for adrenocortical tumors. Surgery, 2013, 154, 1224-1229.

[31] Szabó, D. R., Luconi, M., Szabó, P. M., et al.: Analysis of circulating microRNAs in adrenocortical tumors. Lab. Invest., 2013, 94, 331-339.

[32] Igaz, I., Nyiroó, G., Nagy, Z., et al.: Analysis of circulating microRNAs in vivo following administration of dexamethasone and adrenocorticotropin. Int. J. Endocrinol., 2015, 2015, 589230.

[33] Patterson, E., Webb, R., Weisbrod, A., et al.: The microRNA expression changes associated with malignancy and SDHB mutation in pheochromocytoma. Endocr. Relat. Cancer, 2012, 19, 157-166

[34] Murray, M. J., Halsall, D. J., Hook, Elizabeth C.. et al.: Identification of microRNAs from the miR-371 373 and miR-302 clusters as potential serum biomarkers of malignant germ cell tumors. Am. J. Clin. Pathol., 2011, 135, 119-125.

[35] Dieckmann, K. P., Spiekermann, M., Balks, T., et al.: MicroRNAs miR-371-3 in serum as diagnostic tools in the management of testicular germ cell tumours. Br. J. Cancer, 2012, 107, 17541760.

[36] Syring, I., Bartels, J., Holdenrieder, S., et al.: Circulating serum miRNA (miR-367-3p, miR-37la-3p, miR-372-3p and miR373-3p) as biomarkers in patients with testicular germ cell cancer. J. Urol., 2015, 193, 331-337.

[37] Dieckmann, K. P., Spiekermann, M., Balks, T., et al.: MicroRNA miR-37la-3p - A novel serum biomarker of testicular germ cell tumors: evidence for specificity from measurements in testicular vein blood and in neoplastic hydrocele fluid. Urol. Int., 2016, 97, 76-83.

[38] Flor, I., Spiekermann, M., Löning, T., et al.: Expression of microRNAs of C19MC in different histological types of testicular germ cell tumour. Cancer Genomics Proteomics, 2016, 13, 281289.

[39] Zhang, B., Cai, F. F., Zhong, X. Y.: An overview of biomarkers for the ovarian cancer diagnosis. Eur. J. Obstet. Gynecol. Reprod. Biol., 2011, 158, 119-123.

[40] Kan, C. W., Hahn, M. A., Gard, G. B., et al.: Elevated levels of circulating microRNA-200 family members correlate with serous epithelial ovarian cancer. BMC Cancer, 2012, 12, 627.

[41] $X u$, r. Z., Xi, Q. H., Ge, W. L., et al.: Identification of serum microRNA-2 1 as a biomarker for early detection and prognosis in human epithelial ovarian cancer. Asian Pacific J. Cancer Prev., 2013, 14, 1057-1060.

[42] Hong, F., Li, Y., Xu, Y., et al.: Prognostic significance of serum microRNA-221 expression in human epithelial ovarian cancer. J. Int. Med. Res., 2013, 41, 64-71.

[43] Guo, F., Tian, J., Lin, ., et al.: Serum microRNA-92 expression in patients with ovarian epithelial carcinoma. J. Int. Med. Res., 2013, 41, 1456-1461.

[44] Zheng, H., Zhang, L., Zhao, ., et al.: Plasma miRNAs as diagnostic and prognostic biomarkers for ovarian cancer. PLoS ONE, $2013,8, \mathrm{e} 77853$

[45] Li, A., Үu, J., Kim, H., et al.: MicroRNA array analysis finds elevated serum miR-1290 accurately distinguishes patients with low-stage pancreatic cancer from healthy and disease controls. Clin. Cancer Res., 2013, 19, 3600-3610.

[46] Li, S. C., Essaghir, A., Martijn, C., et al.: Global microRNA profiling of well-differentiated small intestinal neuroendocrine tumors. Mod. Pathol., 2013, 26, 685-696.

[47] Butz, H., Kinga, N., Racz, K., et al.: Circulating miRNAs as biomarkers for endocrine disorders. J. Endocrinol. Invest., 2016, $39,1-10$

[48] Waguespack, S. G., Rich, T., Grubbs, E., et al.: A current review of the etiology, diagnosis, and treatment of pediatric pheochromocytoma and paraganglioma. J. Clin. Endocrinol. Metab., 2010, 95, 2023-2037.

[49] Langhe, R., Norris, L., Saadeh, F. A., et al.: A novel serum microRNA panel to discriminate benign from malignant ovarian disease. Cancer Lett., 2015, 356, 628-636.

[50] Meng, X., Müller, V., Milde-Langosch, K., et al.: Diagnostic and prognostic relevance of circulating exosomal miR-373, miR$200 \mathrm{a}$, miR-200b and miR-200c in patients with epithelial ovarian cancer. Oncotarget, 2016, 7, 16923-16935.

(Igaz Péter dr., Budapest, Üllői út 26., 1085 e-mail: igaz.peter@med.semmelweis-univ.hu)

\section{Tisztelt Szerzőink, Olvasóink!}

Az Orvosi Hetilapban megjelenö/megjelent közlemények elérhetőségére több lehetőség kínálkozik.

Rendelhetö különlenyomat, melynek áráról bövebben a www.akkrt.hu honlapon (Folyóirat Szerzöknek, Különlenyomat menüpont alatt) vagy Szerkesztőségünkben tájékozódhatnak.

A közlemények megvásárolhatók pdff-formátumban is, illetve igényelhetö Optional Open Article (www.oopenart.com).

Adott dij ellenében az online közlemények bárki számára hozzáférhetök honlapunkon (a közlemények külön linket kapnak, így más oldalról is linkelhetővé válnak).

Bővebb információ a hirdetes@akkrt.hu címen vagy különlenyomat rendelése esetén a Szerkesztőségtől kérhető. 